\title{
Fun Cooking to Increase Early Childhood Learning Motivation During Covid-19 Pandemic
}

\author{
Erna Budiarti $1^{*}$ \\ ${ }^{1}$ Panca Sakti University Bekasi \\ *Corresponding author.E-mail: bbbudiarti@gmail.com
}

\begin{abstract}
This research is considered important to describe learning motivation in Early Childhood from home during the outbreak of the Coronavirus. Fun cooking activity is one of the activities that are useful for early childhood in reducing canned food produced abroad by cooking healthy food at home with family. This learning method is also interesting to increase learning motivation in early childhood. As an education and curriculum consultant in implementing Merdeka Belajar (Freedom of Learning) in the face of disasters that require adherence to health regulations by studying at home, maintaining distance, a healthy lifestyle, washing hands, and checking body temperature during the Covid-19 pandemic. It can be concluded that children's motivation can be built by expressing themselves starting with a sense of being at home, communicating more closely, and appreciating the use of various learning media at home while playing Fun Cooking.
\end{abstract}

Keywords: Early childhood, motivation, learning from home, fun cooking

\section{INTRODUCTION}

Early Childhood Education (ECE) aims to develop abilities, shape character and habituation so that children's potential will increase with a strong character of faith and always be responsible for themselves and the environment. Playing as a group is absolutely necessary to develop creativity, imagination, feelings, will and motivation Early Childhood included The Special Needs Children [1]. Because currently in the Covid-19 pandemic, what is meant by playing as a group is playing with family members at home through playing fun cooking.

The global of Covid-19 outbreak with symptoms of cough, shortness, fever then gives early warning to children to get used to maintaining distance, introducing a new way of greeting, initially kissing the hand is changed to simply giving hand signals, wearing masks, maintaining hand hygiene, consuming healthy food and preventing anxiety so that the immune system is strong and pray at home. The importance of adhering to health protocols, prevention is better than cure when sick. Cognitive refers to mental activity about how information is entered into the mind, stored, and transformed and recalled and used in complex activities such as thinking [2].

The use of internet technology in Early Childhood during this pandemic helps children to increase children's motivation in improving ways of thinking, exploration, and action through play experiences [3]. The problem can be formulated, namely how fun cooking can increase motivation by stimulating learning and can take advantage of the environment at home.

Based on the formulation of the problem, the general objective of this study is to utilize the home environment for learning, activities through fun cooking and discipline activities. The specific goal is to increase learning motivation.

\section{METHOD}

The research was conducted on learning motivation at home during COVID-19 using qualitative research methods. The implementation of in-depth observation in COVID-19 was done by playing the fun cooking at home for Early Childhood (4-5 years old-group A) with a total of 10 children with 3 boys and 7 girls. This study uses triangulation of sources and methods to uncover and compile data found from observations, interviews, and documentations. Data analysis techniques consist of three components of data reduction, presentation of data withdrawal and testing of conclusions [4].

\section{RESULT AND DISCUSSION}

Based on the results of the research that through fun cooking activities in utilizing the home environment, children's needs for activity and discipline can increase learning motivation. The observations that the 
researchers found directly in the field, it was seen that children did not understand the concept of healthy food, did not take advantage of the time to help prepare food at home and while worshiping was less orderly and learning motivation was low so that the expected indicators had not been achieved. In addition, playing has a direct role in the development of children's cognition [5].

Learning from home in collaboration through fun cooking games between children and parents can achieve developmental aspects that include moral, social, emotional, language, cognitive, physical/motor and artistic values. Fun cooking games are designed to introduce new concepts of home learning during pandemics. However, the challenge of learning through playing fun cooking at home is of course a challenge for teachers, parents and children themselves. This fun cooking activity can also be supported by technology, especially cell phones, to support documentation activities. Photographs of children doing activities with parents should be documented as input for teaching at home [6].

The presence of a teacher cannot be replaced by technology after two weeks of learning to use technology, the children are getting bored. Even though they face to face with the teacher online, children feel that they are missing the presence of teachers and friends and cannot wait for the school atmosphere so that learning motivation is low.

Cognitive is a mental activity in knowing and knowing about the outside world [7]. Before the activity is carried out the teacher creates children's readiness to learn fun cooking by stimulating children's motivation.

Skills that can be developed by early childhood by playing fun cooking in improving knowledge, skills, and attitudes are implemented in the following ways:

Clean living environment. All children's activities that were originally carried out at school and visiting friends' houses finally focused on all activities at home because of the coronavirus. Outdoor activities in the home environment in the morning make you happy. Change clothes after outside activities. Environmental hygiene including maintaining the health of the school environment to be clean and tidy, this can be done by instilling behaviour to maintain a clean environment [8]. The habit of maintaining personal hygiene and the environment is very appropriate to be instilled early on because the habit will carry over into adulthood.

Learn the art of cooking. Growth and development of children are greatly influenced by nutritional intake. Cooking instances should be avoided and avoid canned foods. Simple food menu decorated with vegetables, fresh fruit becomes attractive and healthy. It has stated that increasing cooking interventions in children should be started at an early age. Cooking skills have been shown to increase a confident, healthy attitude through food choices [9].

Try new recipes. Fun activity by trying new recipes. Modifying traditional recipes to be contemporary. Get to know the herbal turmeric (jamu kunyit) drink for endurance, combined with pudding and snacks according to children's tastes. The use of fun cooking as a good and adequate learning model is expected to stimulate thoughts, feelings, attention, and interest in Early Childhood [10].

Build a frugal life. Economic crisis due to Covid-19. Stop eating before you are full, avoid excessive. Planting live pharmacies, hydroponic vegetables and raising fish in drums are alternative activities that are highly economically valuable. Children who have focused on simple life will have high thinking power, trying to live independently and economically [11].

Pay attention to the halal label, expiration and nutritional content. In addition to knowing the benefits, children are also trained to read and know the size of the fat, and protein content. From a Muslim perspective, consuming halal food and halal drinks is not only needed for physical health but also good for spiritual development [12].

Work in teams or collaborate. Every activity, if done in a team with family members, will feel light and reduce stress and socialize. Learning various skills as a group helps the development of the child as a whole, because group learning affects various areas of psychophysical development in a similar way such as recognition, perception, and problem solving through motor activity [13].

Show your cooking results with confidence. Respecting yourself is the beginning of self-confidence to convey tasteful work through social media. Learning skills at different ages: a cross-sectional study. It stated that learning to cook in Early Childhood has been linked to higher self-confidence and more time in the kitchen is a way to increase self-confidence in children [9].

The purpose of this fun cooking activity program is also to form a strong personality because they have different talents and abilities and all of them are useful for them in the future.

Worship on time. Early Childhood motivation to always appreciate the time to be used properly will teach discipline and cleanliness to Early Childhood. Asking God for Covid-19 to pass immediately through worship. Discipline in worship needs to be taught so that later children understand Islamic teachings and have guidelines in their life". In addition, especially the discipline of teaching habituation to follow children's prayer movements, is done in a way that is already in the Qur'an [14]. There are two factors that influence character formation in early childhood, including children with special needs, namely the child's innate 
nature and the child's view of the world they have, such as knowledge, experience, accepted moral principles, guidance, and direction from parents.

\section{CONCLUSION}

Based on the research findings that have been carried out by learning activities during Covid-19, parents and teachers must pay attention to 8 things to maintain Early Childhood motivation as an answer to the problem formulation, it can be concluded as follows:

1. Clean living environment.

2. Learn the art of cooking.

3. Try new recipes.

4. Build a frugal life.

5. Pay attention to the halal label, expiration and nutritional content.

6. Work in teams or collaborate.

7. Show your cooking results with confidence.

8. Worship on time.

An interesting conclusion from the research here is the finding of the problem formulation, namely independence in choosing activities. When sharing, the brain will produce the hormone dopamine which produces feelings of happiness and the hormone oxytocin which reduces stress, which causes motivation [15].

Children can share food by playing fun cooking at home with others as a form of concern for their own health during the pandemic. Playing fun cooking through cooking healthy food is needed by the child's body so that the immune system is strong, producing happy feelings and reducing the stress that causes motivation.

Based on the conclusions, the article proposes to build a healthy environment in the future, and the teacher in collaboration with parents must be able to understand themselves when the child is bored, it is necessary to innovate life skills education in the New Normal Era so that motivated to learn to be better and care for others so that they can live side by side with Covid-19.

\section{ACKNOWLEDGMENTS}

The author would like to thank all those who have provided assistance in this research. All leaders and academics of the Panca Sakti University, Early Childhood Teachers, Employees at Nurul Aulia Kindergarten, and family who always supported me in completing this research.

\section{REFERENCES}

[1] Budiarti E, Handini MC, Dlis F. Buku panduan cara melatih anak usia dini bermain pencak silat ceria. Jakarta: CV Prima Print; 2018.

[2] Santrock JW. Life-span development. 13 th Edition. University of Texas, Dallas: Mc Graw-Hill; 2012.

[3] Budiarti E. Case study of "gifted children", Proceedings of the National Seminar on Intervention of Children with Special Needs, Jakarta, 4 August 2016.

[4] Budiarti E. How to give motivation, encouragement, and conduct exciting activities toward slow learner children. In Semarang Early Childhood Research and Education Talks (Secret). Proceeding Internasional Conference: Semarang 13-14 Mei 2016. 2016:401-11. Semarang: Universitas Negeri Semarang.

[5] Vygotsky L. Mind in society: The development of higher psychological processes. Cambridge: Harvard University Press. 1978.

[6] Budiarti E. Evaluasi pelaksanaan program kegiatan belajar membangun karakter anak usia dini melalui berbagai media. Jakarta: Uhamka; 2014.

[7] Hurlock EB. Developmental Psychology: A lifespan approach. New York: McGraw-Hill; 1980.

[8] Suyatmin S, Sukardi. Development of hygiene and healthy living habits learning module for early childhood education teachers, Unnes Journal of Public Health. 2018;7(2):89-97.

[9] Lavelle F, Spence M, Hollywood L. McGowan D, Surgenor A, McCloat E, Mooney M, Caraher, M, Raats M, Dean. Learning cooking skills at different ages: a cross-sectional study, International Journal of Behavioral Nutrition and Physical Activity. 2016;13(119):1-11.

[10]Riska N, Kandriasari A. The Effectiveness of fun cooking learning model against multimedia-based for children aged 5-6 years. International Journal of Academic Research. September 2017.

[11] Kasser T. Frugality, generosity, and materialism in children and adolescents. In What do children need to flourish? 2005 (pp.357-373). Boston: Springer.

[12] Wahyudin D, Rahmawati A, Suwirta. The teaching of halal food in school's curriculum in Indonesia. SIPATAHOENAN: South-East Asian Journal for Youth, Sports \& Health Education, October 2018;4(2).

[13] Oblak P. The young learner and learning the language through the vehicle of sport. Case study. Oxford: Oxford Brookes University; 2003.

[14] Wakhidah LM, Khamidun K. The discipline character in the prayer movements of hyperactive 
children in State Special School (SLB) Ungaran and Kemala Bhayangkari 90 kindergarten Semarang Police Academy. BELIA: Early Childhood Education Papers. 2018 Nov 23;7(2):62-8.

[15]Fábio da Silva Ferreira1, Renato Lopes da Costa, Leandro Pereira, Carlos Jerónimo and Álvaro Dia. The relationship between chemical of happiness, chemical of stress, leadership, motivation and organizational trust: a case study on Brazilian workers. Journal of International Business and Economics. December 2018;6(2):89-100. Available from: https://doi.org/10. 15640/jibe.v6n. 